\title{
FOOD RESOURCES AS THE BASIS OF THE SUSTAINABLE DEVELOPMENT AND NATIONAL SECURITY IN THE AGE OF ECONOMIC GLOBALIZATION
}

\author{
Vladimir I. SAVKIN, Nina A. PERVYKH
}

\author{
Orel State Agrarian University, Orel, Russia
}

\begin{abstract}
Development of society is based on the existence of food resources. During the modern technogenic era, mankind needs to find a compromise between growing needs for the food and limitation of resources. Many countries still cannot use the world experience which effectively ensures food safety. Development of strategically important branches of agriculture and formation of laws according to which the basic food has to be made within the country by forces of its own producers has to become the condition of the problem solution. In Russia, a certain reserve in achievement of threshold values ensuring food safety of the state is already created. At the same time, the problem direction is the production of meat and milk. Among priorities there has to be a creation of modern infrastructure in order to decrease the storage expenses, transportation, and production realization. The agrarian policy of the Russian Federation has to be focused on the system management, including scientific, staffing and financial support, institutional modernization, the application of global experience, and also super-compliance of the economic agents' rights.
\end{abstract}

Keywords: food resources, sustainable development, agrarian economy, the World Trade Organization

\section{Introduction}

The world community today faces numerous and interconnected problems, ranging from consequences of the lasting financial and economic crises to climate change and shortage of food in certain regions of the world. To act against the problems, mankind should look for a compromise between satisfactions of growing food requirements of the population on one hand and limitation of the natural resources providing the basis for agricultural production on the other. The agrarian sector of economy directly and indirectly serves as a food source, and the income for the considerable part of the population of our planet, and the basis of sustainable development of national economies. However, in the world where nearly a billion inhabitants still suffer from hunger, poor groups of the population, especially in rural areas, are the most vulnerable to cumulative impact of the threats stated above.

In spite of the high rates of economic globalization and expansion of the World Trade Organization (WTO) role, indicators of production and consumption of food remain the lowest in many countries. The governments of the majority of states still do not manage to use the experience, which is effectively available in the world and ensures food safety, growth of the income of villagers and sustainable development. In the next decades the problem of shortage of food will come out on top in the world. According to the UN data, population of the Earth in 2010 reached 6.8 billion people, and by 2050 , it will exceed 10 billion people, which is 4 times more than the critical threshold of the biosphere stability. According to the estimates of the Food and Agricultural Organization UN (FA0), the demand for food in the world will increase twice by 2050 , and $80 \%$ growth of the food outputs will be provided at the expense of gross collecting grain strengthening Kudrov (1968).

Expansion of agricultural production and strengthening of the world food security are still interfered by a number of problems to which, according to FAO belong: irrational management, weakness of regulation modes, collision in the field of using natural resources, proceeding application of unproductive methods, inability to consider priorities and the rights of the communities which are engaged in small-scale production, and also the manifestations of injustice connected with gender discrimination and child labour Kudrov (1968).

Recent Conference of the UN on sustainable development (known as 'Rio $+20^{\prime}$ ), became a place of discussion of the questions connected with management, and formed a basis for confirmation of commitment to sustainable development from a position of the performed progress assessment and definition of arising new problems in providing mankind with food resources. The strategic directions of work in national economies, according to FAO have to be, for today, the achievement of high level of food security as well as spending less amount of natural resources by improvement of management and efficiency increase on all extent ofproduction and marketing food chain, i.e. bigger results, smaller means (effective production).

\section{Material and methods}

The modern world economic relations and the accession of Russia to the WTO demand indicators of an assessment of food security of the country, the concept of its formation and the implementation mechanism. In this regard, the current food security of the Russian Federation is one of the main directions of ensuring its national security, the factor of its statehood and sovereignty protection. The most important role of Russia (as the owner of huge resource potential - the tenth part of the world arable lands, a quarter of freshwater resources, etc.) in supplying and global food security should be noted. The Russian Federation is the largest country in terms of the territory and it is also included into the top four countries in terms of arable land possesion (fig. 1).

At the same time, from the objective point of view, it should be noted that more than a half of the Russia territory are underproductive lands (the North of the European part of the country and the most of Siberia part and the Far East). More productive lands differ widely in degree of natural fertility that is connected, first of all, with a frigid climate and the long period of negative temperatures (the short vegetative period, spring frosts, etc.) that increases agricultural risks of production. However, only the Russian Federation, having 86 hectares on 100 people of the population, possesses the production 


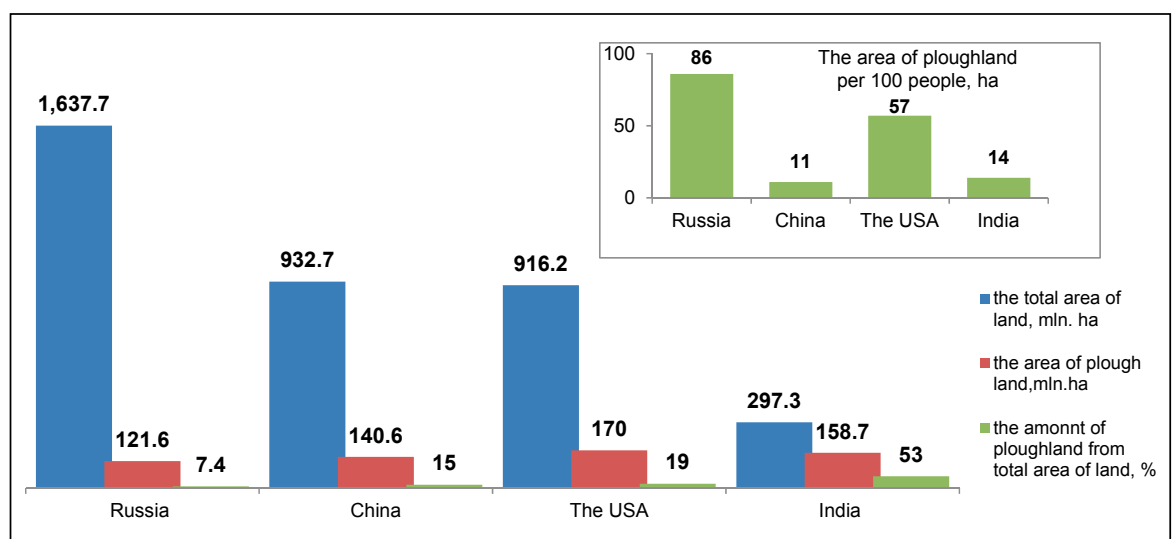

Figure 1 The leading countries on land resources Source: Savkin and Proka, 2012

potential of required amount of high quality food resources.

In this regard, further in discussion of results we use economic comparisons of the international complex economic and statistic factors, directed on comparison of their natural and value terms over the various countries (The official website of The Ministry...., 2012). All this is carried out due to objective studying of levels, structure and tendencies of economic development of the different countries, which allows opening reserves of production and its efficiency in the Russian Federation.

\section{Results and discussion}

Program documents of agricultural development in the Russian Federation (The State program for the development of agriculture and regulation of the markets of agricultural production, raw materials and food for 2008-2012; The State program for the development of agriculture and regulations of the markets of agricultural production, raw materials and food for 20132020) provide for increasing (in the mid-term perspective significantly) the share of Russia in the world balance of the food: grains, oil-bearing crops, sugar, fowl, pork (The official website of The Ministry...., 2012). However, the essential change in the agrarian policy, in the mechanism of distribution of financial resources and in the constructive justification of foreign economic activity is necessary for this purpose.

It is possible to consider grain and products of its processing, beef and poultry meat, and also milk, as main food resources providing contribution to national security. Certainly, there are considerable gradations of priorities of one or another product within national economies (Japan - rice and seafood, Nordic countries seafood, etc.). That is connected with mentality and the established traditions.
Sustainable development of strategically important branches of agriculture has to become the condition of the problem solution for ensuring food security on one hand, which means the increase in volumes and specific weight of domestic production in the total amount of commodity resources of the country, Source: Savkin and Proka, 2012 Source: Savkin and Proka, 2012 and on the other hand, the formation of laws according to which the basic food has to be made within the country by forces of its own producers. The realities of our time show that the leading countries of the world manage to do it (fig. 2, 3 and 4).

China, the USA and India are the world leaders in production of grain; China, the USA and Russia are the leaders in production of beef and poultry meat; the USA, India, Russia and China are the leaders in milk production. However, the food security of the countries is defined not only by gross production of any given products, but also by the ratio of its own production and the import share.

According to The doctrine of food security of the Russian Federation, approved by the Decree of the President No. 120 of January 30, 2010 for an assessment of the food security condition, the following notions are used as criteria: the specific weight of domestic agricultural, fish production and food production in the total

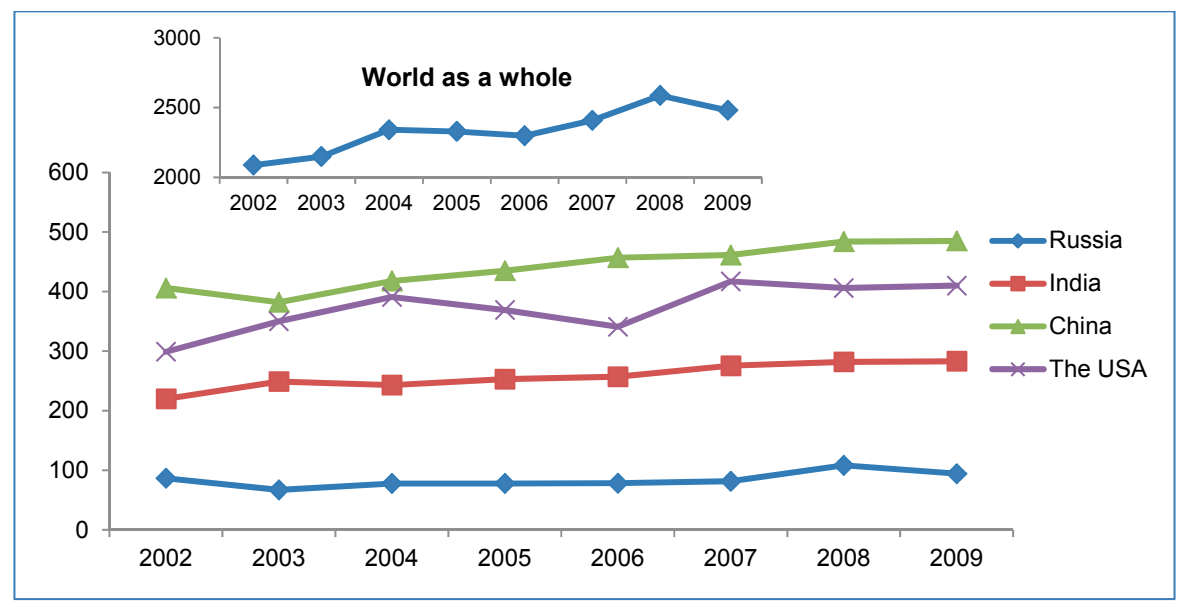

Figure 2 Production of grain by the biggest countries in terms of area in mil.t

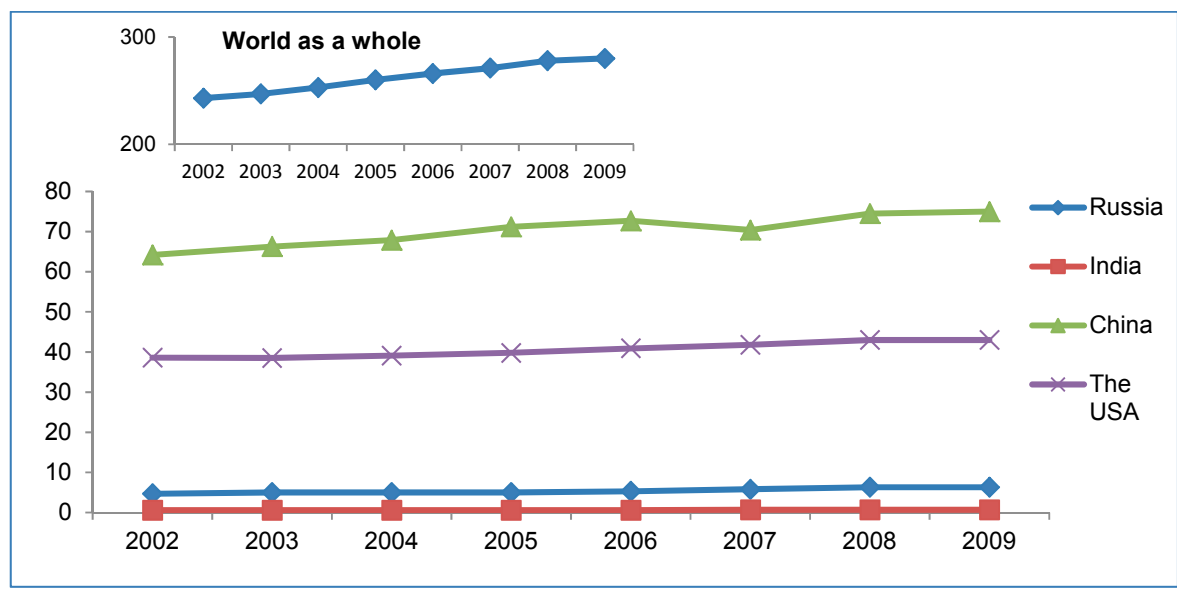

Figure 3 Production of cattle and poultry by the biggest countries in terms of area in mil.t 


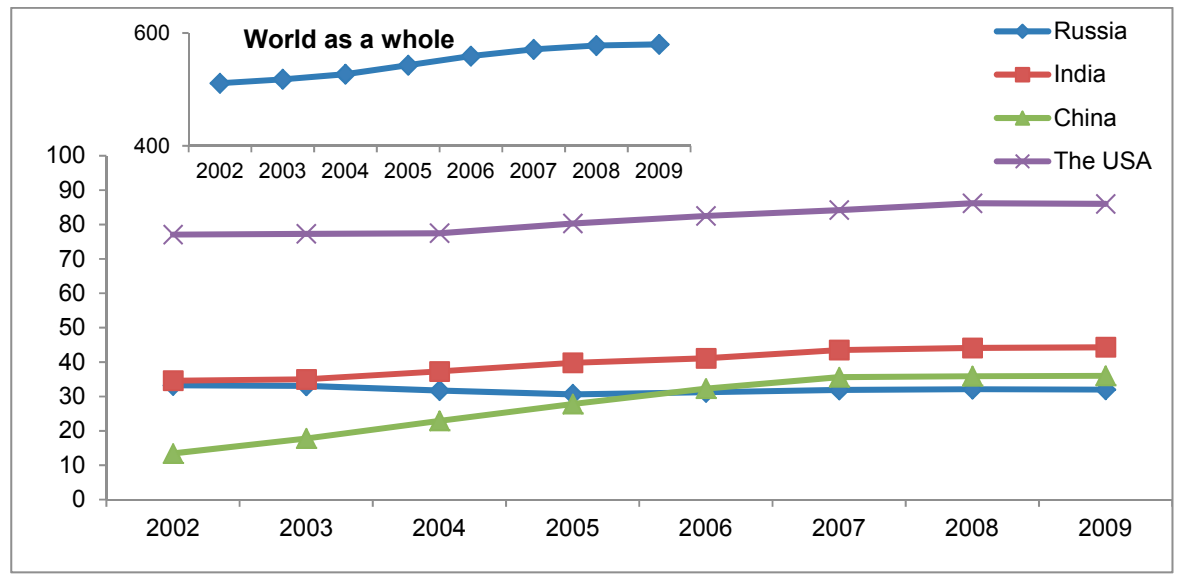

Figure 4 Production of milk by the biggest countries in terms of area in mil.t Source: Savkin and Proka, 2012

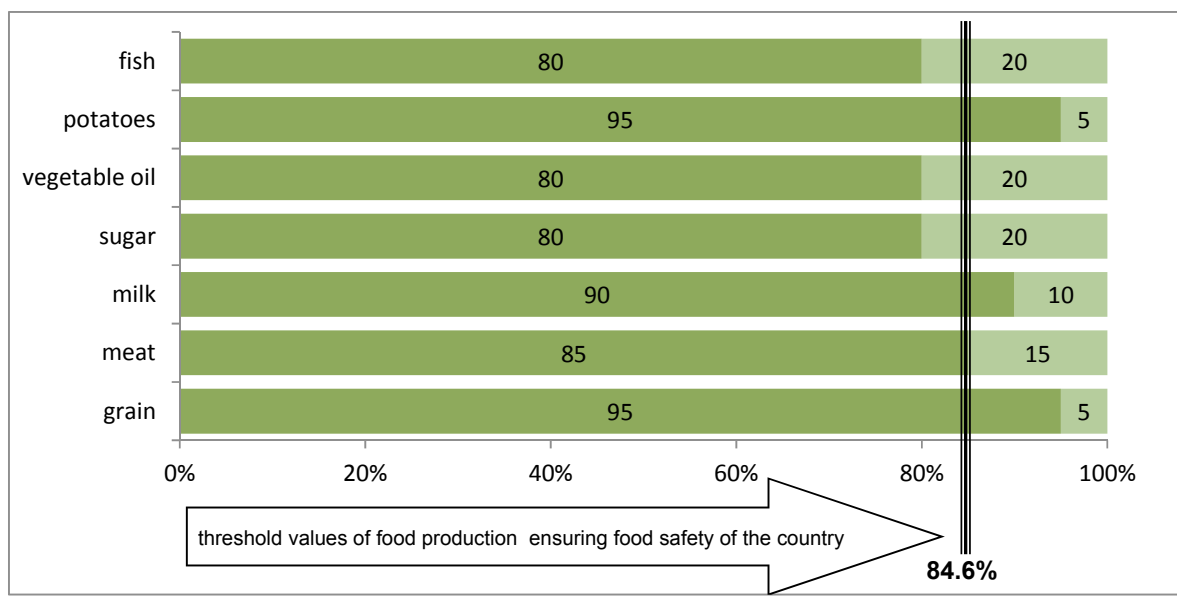

Figure 5 Threshold values in \% of food productions from the requirement ensuring food safety of the Russian Federation

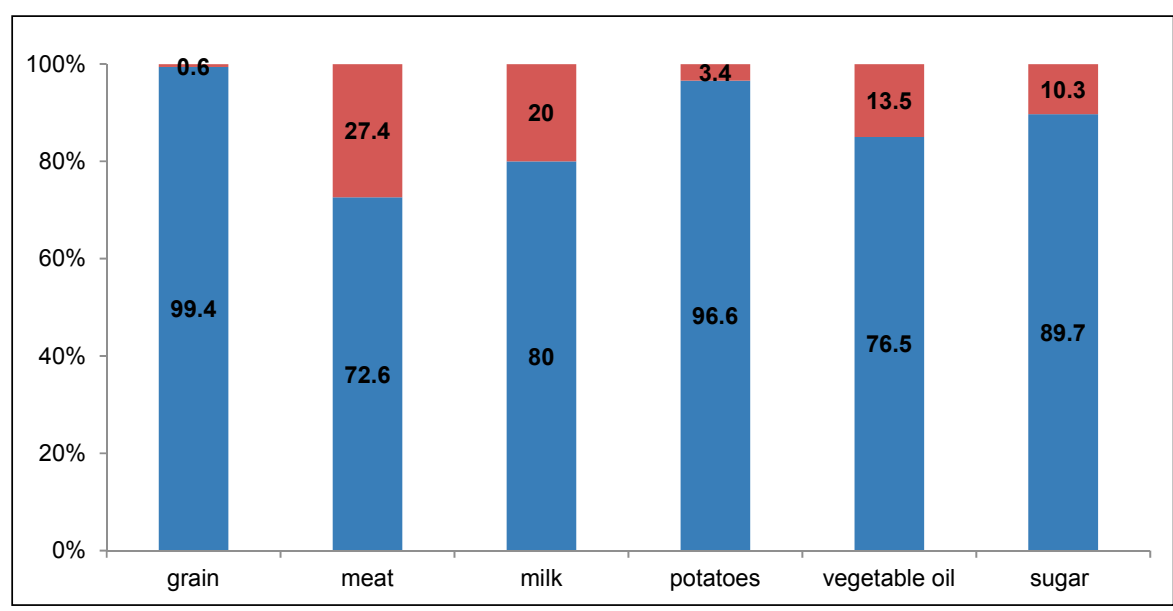

Figure 6 The state of food security in the Russian Federation in terms of the main resources, 2010 Source: Savkin and Proka, 2012

amount of commodity resources (taking into account carryover storage), domestic market of the corresponding products, having threshold values taken into account (The official site of the President..., 2012) (fig. 5).
For domestic (the Russian Federation) manufactures of products, these standard parameters are an imperative, and their achievement has to be based on programs of development of separate branches with definition of terms, volumes and funding sources, directing the modernization of economy.

Measures of the current state support of domestic producers are based on the results of carried-out monitoring of the food security condition in the country and in the regions, including 335 indicators. The information system of food balances, created by the Ministry of Agriculture of the Russian Federation is the basis for an assessment of the food safety and domestic market conditions in the circumstances of participation of the country in the WTO. In Russia, certain reserves in achievement of threshold values for ensuring food safety of the main food products (fig. 6) are created for the last years.

It should be noted that the essential progress in crops growing branch allowed the country not only to provide for its own needs for grain, but also to enter the world market with this strategic resource. In 2009-2010 agricultural year, grain export made 18.275 million tons from Russia, and in 2011-2012 by certain estimates, more than 20 million tons will be taken out from Russia and sold abroad. At the same time it is necessary to consider production of grain as the basis for the domestic animal husbandry development, moreover, the Russian Federation is only close to the threshold values in this direction (meat: 2010 - 72,6\%; milk: $2010-80 \%)$, characterizing food security of the country.

Volumes and structure of production, consumption and the size of self-sufficiency of the main food stuff play an important role in definition of priorities for food security. Domestic food resources need to be considered, first of all, from a position of their priority consumption by own population, and also utilization in domestic sectors of the industry for the purposes of manufacturing bigger added value products. In this regard, the most objective criterion, characterizing both national food security and the population standard of living, is consumption of the main foodstuff per capita (fig. 7).

As for today, the acute problems of the agricultural production development in the Russian Federation demand formation of the whole complex of the actions, capable to provide the increase in the production of qualitative and cheap food resources. The solving of these problems efines the food safety of the country. As the main food resources, providing sustainable development of the national economy and its national security, we can consider grain (grain products), meat and meat products, milk and dairy products. 


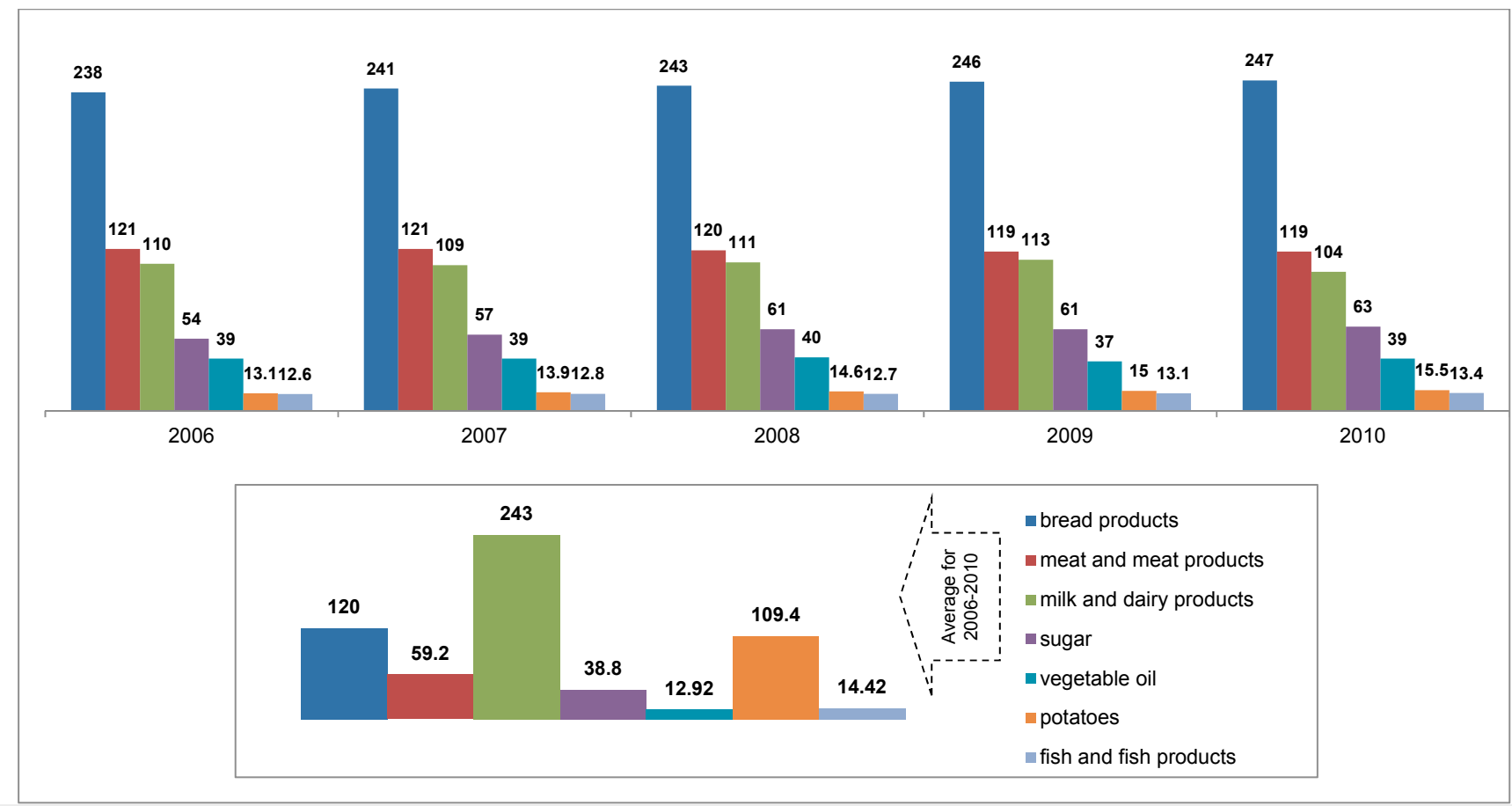

Figure 7 Consumption of the main food per capita in the Russian Federation in $\mathrm{kg}$ Source: Savkin and Proka, 2012

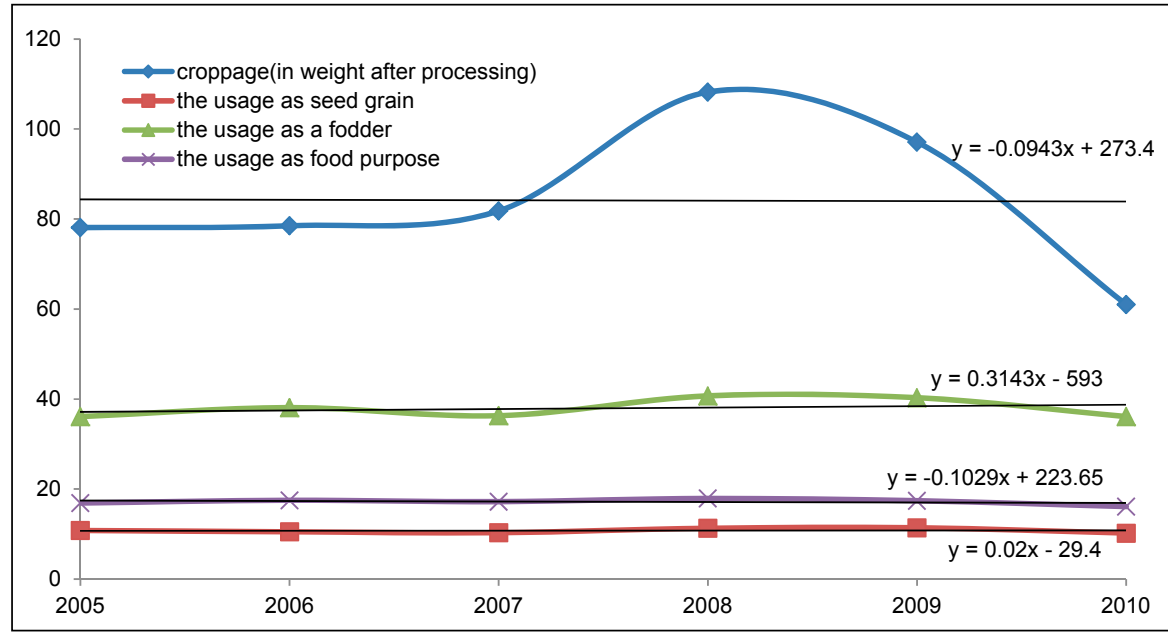

Figure 8 Production and grain use in the Russian Federation in mil.t Source: Savkin and Proka, 2012

The efficiency of the grain farming in the Russian Federation is defined by territorialeconomic branch division, caused more by climate and environmental conditions (at the expense of an interregional exchange becomes covered to $20-25 \%$ of requirement for food and fodder grain). The most important achievement of agrarian and industrial complex of Russia is the implementation of indicators of the Doctrine of food security on main types of plant growing production (in 2011, more than 94 million tons were gathered; the export potential of the country in supply of grain to the world market is restored). Despite an ascending trend of its production dynamics, dependence of production of grain on weather conditions is observed. Future use of the grain crops is important, except receiving its high croppage (fig. 8).

Production of grain in the country is much higher than its consumption and such positive dynamics stimulates development of other directions of the production, ensuring food safety, such as animal husbandry, deep processing of raw materials. This fact is important also because the food security of the Russian Federation, in our opinion, is necessary to be considered both on nation-wide and one hand, a big differentiation in the range of products, and on the other hand, the need for regional level, as in the country there is, on alignment of conditions and quality of life of the population of regions.

The current state of the food resources market testifies to low level of self-reliance of the Russian Federation in meat and meat products, milk and dairy products. The import share thus remains quite high. According to "The concept of long-term social and economic development of the Russian Federation till 2020", Russia has to come to the desired level of consumption of meat and meat products only by 2020 (fig. 9).

By separate estimates, the implementation of the program of agricultural development promoted the increase in production of cattle and poultry on slaughter in live weight basis to 11 million tonnes by 2012. In 2011, the number of cattle increased to level of 2010 - by 100 thousand heads for the first time in the last 20 years in Russia.

It is possible to call dairy production one of the three pillars on whom the food security of the countries all over the world including the Russian Federation stands. According to the official data of FAO, milk outputs increase in the world. In Russia in recent years the production of milk was stabilized at the level of 32 million tonnes, thus, however, lagging behind growth rates of the population (fig. 10).

The Russian market of milk and dairy products is not protected against the competition with import. And the offer lags behind the demand, which conducts to constant increase in import of milk. It is important to note that 


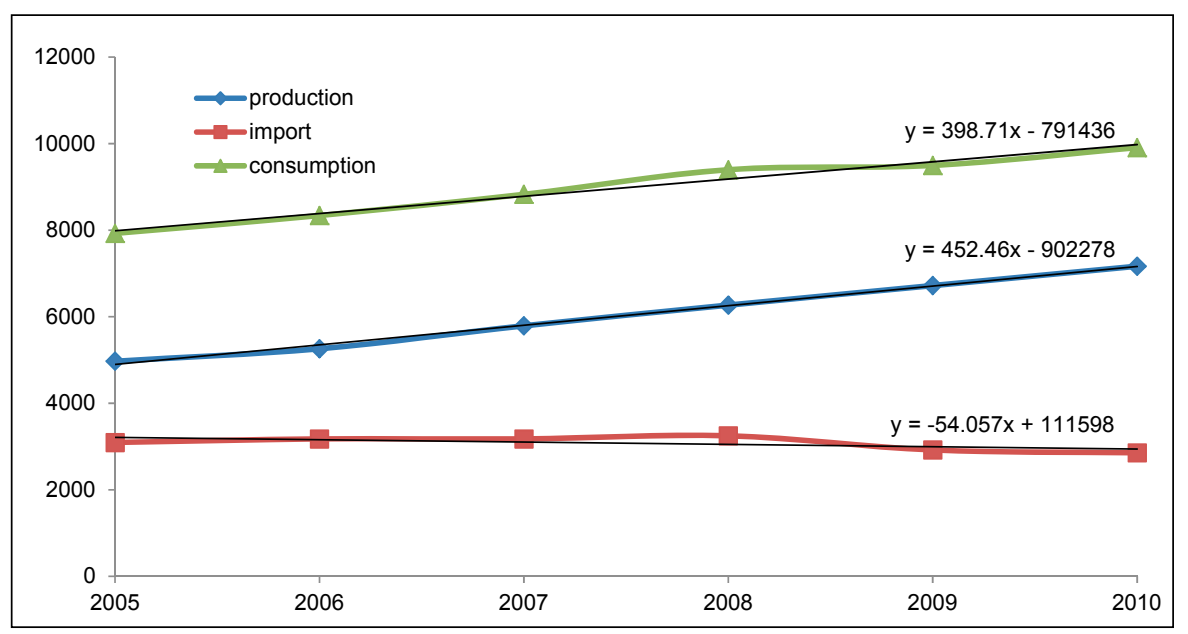

Figure 9 Resources and the usage of meat and meat products in the Russian Federation in thous. $t$ Source: Savkin and Proka, 2012

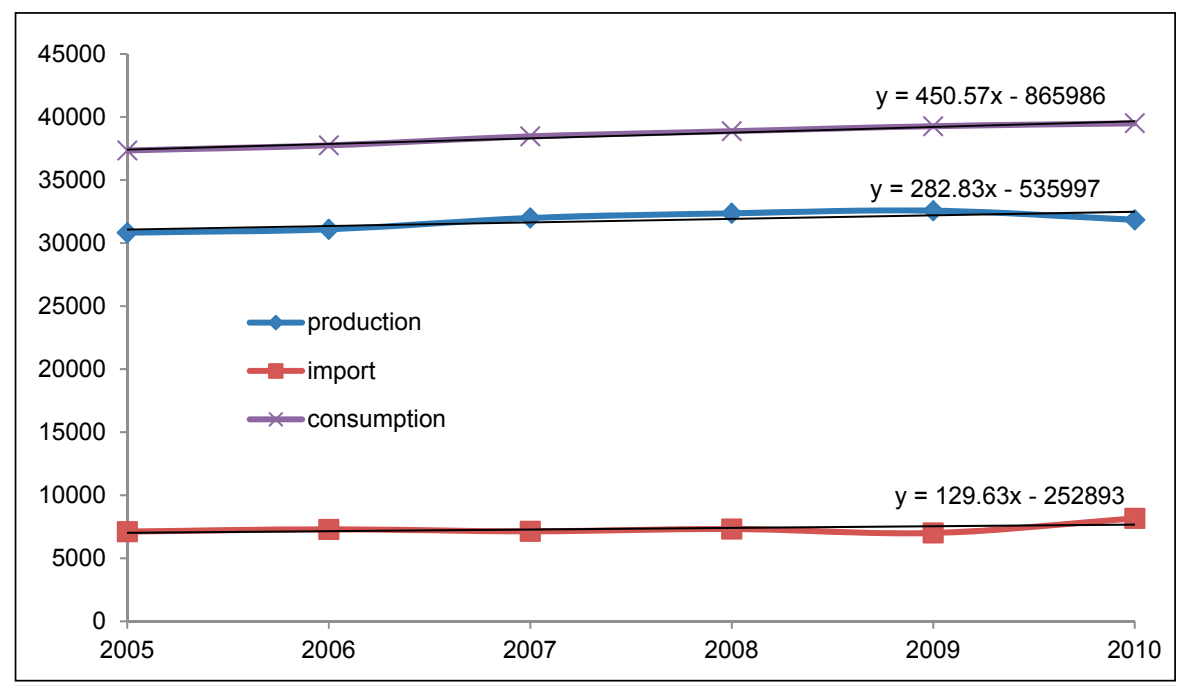

Figure 10 Resources and the use of milk and dairy products in the Russian Federation in thous. $t$ Source: Savkin and Proka, 2012

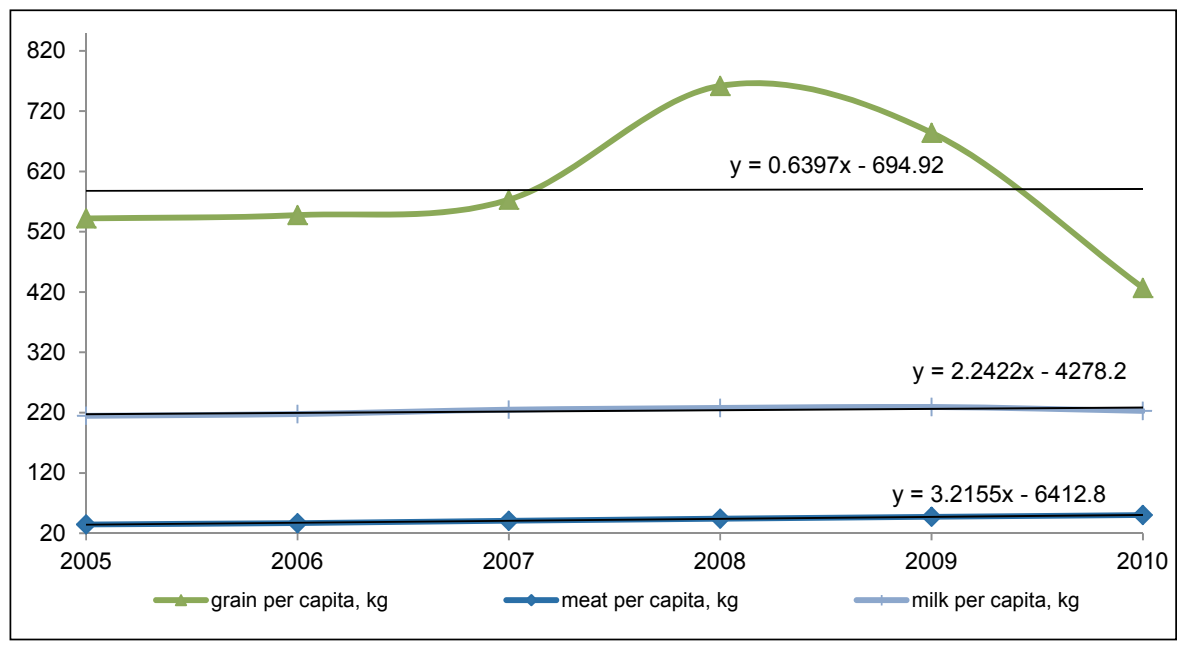

Figure 11 Production of the main food resources per capita in the Russian Federation in $\mathrm{kg}$ Source: Savkin and Proka, 2012 in 2009, Russia reduced the import volume of dairy products from $18.2 \%$ in 2008 to $16.8 \%$. However, in the drought of 2010 in connection with the decrease in outputs of milk and the price advance, there was the growth of the import volumes (especially powdered milk) to $20 \%$, which increased the gap between the actual and threshold value of food security in milk.

Positive shifts are not observed by the types of dairy production. So the self-reliance structure production differs in heterogeneity in various segments of the dairy market. The highest share of self-reliance for Russian people is in the whole-milk production segment (drinking milk and drinking sour-milk products, including sour cream) where the big share of crude commodity milk (70\%) is spent. Other $30 \%$ of crude milk is distributed between producers of cheese, oil, milk-powder and concentrated milk. It is obvious that import compensates the deficiency in these markets.

The reduction of dairy herd number and low milk yields is the damper for the increase of dairy production in comparison with the worldwide average values. The solution of this problem is possible only through the mechanism of the state support (federal and regional level) of this branch, which is carried out today in the following directions:

$\square$ granting subsidy for acquisition of breeding and commodity cattle, the equipment and machines for livestock farms, and also the equipment and machines for the packer branch houses;

$\square$ granting subsidy for construction, reconstruction or modernization of livestock farms and for the packer branch houses;

$\square$ granting subsidy for construction of livestock farms infrastructure and for the packer branch houses.

The food security of the country is caused by an imperative demand of structural shifts of economy in the direction of domestic producers support for the purpose of ensuring internal requirements for food and for creating the decent social standard of living (basic production per capita). The reality testifies about increase of the domestic producer role in providing citizens of the Russian Federation with food resources; however, there is low per capita production of livestock products (fig. 11)

\section{Conclusion}

Based on the above-mentioned, it should be noted that in the conditions of world economy globalization, Russia needs to significantly 
increase its own production of the main food products, especially as for this purpose there are all necessary preconditions and conditions. Undoubtedly, dynamism of the development in agro-industrial sector demands full state support, which defines the necessity for strategic programs development on federal and regional levels. It is possible to note that now the share of the branch support in gross domestic product constantly increases. If in 2003 it made $0.2 \%$ of gross domestic product, this indicator increased to $0.7 \%$ in 2010. We think the minimum threshold value for support in agrarian sector of economy has to be the volume of financings of not less than 3-4\% from country gross domestic product.

The external processes have the direct impact on the development of agrarian branch in Russia, which ensures food safety. Thus, the protectionism of other states in securing their markets limits possibilities of the Russian producers, and joining of Russia to the WTO can bring to the situation when the domestic market can appear under the threat of invasion of import goods. In these conditions, the state has to give support to domestic producers in the direction of stimulation the export of agricultural production, on which the level of food security has been gained. Among priorities there also has to be the creation of modern infrastructure for decrease in expenses at storage, transportation and realization of food products.

All in all, the agrarian policy of the state has to purposefully ensure the food safety of the country on the basis of the system management, including scientific, staffing and financial support, institutional policy, the accounting of the world experience, and also the super-compliance of the rights of economic subjects, that is responsible for a sustainable development of the state.

\section{References}

KUDROV,V. M. 1968. Comparison of levels of the socialist countries economic development, M, 1965; Methodological problems of the international commensurations of cost indexes. Book 1-2, M, 1968. URL:http://dic.academic.ru/dic.nsf/bse/153221 (date of the address 16. 12. 2012).

SAVKIN, V. I. - PROKA, N. I. 2012. Food security of the state: from the production economics to consumer economics. Education, science and production, 2012, no. 1, p. 14-21.

THE OFFICIAL website of The Ministry of Agriculture of the Russian Federation. URL: http:// $\mathrm{mcx} . \mathrm{ru} /$ documents/document/show/16834.342.htm (address date: 16. 12. 2012).

THE OFFICIAL site of the President of the Russian Federation. URL: http://kremlin.ru/ acts/6752 (address date: 16. 12. 2012).

THE OFFICIAL FA0 website. URL: http://www.fao.org/index_en.htm (address date: 16. 12. 2012).

THE OFFICIAL website of the Federal State Statistics Service of the Russian Federation. URL: http://www.gks.ru/wps/wcm/connect/rosstat/rosstatsite/main/comparison/ (address date: 16. 12. 2012).

\section{Contact address}

Vladimir I. Savkin, Doctor of Economics, Associate Professor, Orel State Agrarian University, Department of Entrepreneurial Business Organization and Management in Agrarian and Industrial Complex, 302019. Russian Federation, Orel region, Orel, General Rodin Str., 69, phone (4862) 45-40-89, Fax (4862) 43-03-14, e-mail: v.i.savkin@mail.ru

Nina A. Pervykh, Ph.D. in Economics, Associate Professor, Orel State Agrarian University, 302019. Russia, Orel, General Rodin Str., 69, phone (4862) 7621-77 